\title{
QUE FEZ SÃO TOMÁS DE AQUINO DIANTE DE KARL MARX
}

\author{
Grimaldo Carneiro Zachariadhes
}

Que faria São Tomás de Aquino, o comentador de Aristóteles, diante de Karl Marx? Este foi o título de uma palestra realizada na Universidade de Chicago, no dia 29 de outubro de 1974, pelo então arcebispo de Olinda e Recife, Dom Helder Câmara, para a comemoração do $7 .^{\circ}$ centenário da morte de São Tomás de Aquino. O sacerdote, nesta ocasião, fez um desafio para a universidade americana: que fizesse com o pensador Karl Marx o que São Tomás fizera com Aristóteles, ou seja, reinterpretasse-o, retirando dele aquilo que era positivo. E aos que poderiam se negar a fazê-lo, alegando que Marx era "materialista, ateísta militante, agitador, subversivo, anticristão", ele lembrava que quando um homem:

“empolga milhões de criaturas humanas, sobretudo de jovens; quando um homem inspira a vida e a morte de grande parte da humanidade, e faz poderosos da terra tremer de ódio e de medo, este homem merece que o estudemos, como certamente o estudaria quem enfrentou Aristóteles e dele soube destacar tudo o que havia de certo" (Câmara, 1975, p. 53). 
Este artigo pretende analisar o Que fez São Tomás de Aquino diante de Karl Marx, isto é, como se deu este diálogo entre católicos - especialmente os jesuítas - e marxistas, principalmente durante a segunda metade do século XX, no Brasil. Vou privilegiar neste texto o Centro de Estudos e Ação Social (Ceas) e buscar compreender como esta instituição, fundada pela Companhia de Jesus, promoveu este diálogo e como reinterpretou o marxismo com base na sua visão cristã, utilizando como fontes principalmente a sua revista intitulada Cadernos do Ceas.

\section{0 conflito aberto}

Em 1937, Pio XI publicava a encíclica Divini Redemptoris, na qual demonstrava aos católicos sua preocupação com o comunismo ateu, reafirmando as condenações feitas pelos seus predecessores e por ele mesmo em outros momentos. O Papa se preocupava com o crescimento dos comunistas e 110 alertava aos "veneráveis Irmãos" que "não se deixem enganar! O comunismo é intrinsecamente perverso e não se pode admitir em campo nenhum a colaboração com ele". Lembrava que nos países aonde os comunistas chegaram ao poder se manifestava "o ódio dos 'sem-Deus" contra os cristãos (Pio XI, 1937, p. 53).

Esta afirmação papal expressava muito bem as preocupações da Igreja Católica em relação aos comunistas naquele momento. A posição do clero era de enfrentamento aos comunistas, que eram vistos como inimigos que deveriam ser combatidos. ${ }^{1}$ Além da crítica ao ateísmo dos comunistas, os religiosos discordavam da solução que era proposta por

\footnotetext{
1 É necessário também lembrar que havia desconfiança dos comunistas frente a religião (e as Igrejas) como nos bem mostra Lênin: "Todas as religiões e igrejas atuais, todas e quaisquer organizações religiosas, são sempre encaradas pelo marxismo como órgãos da reação burguesa que servem para defender a exploração e para entontecer a classe operária". Disponível em: http:/ /www.vermelho.org.br/ diario/2005/0430/bernardo_0430.asp?NOME=Bernardo\%20Joffily\&COD=4413. Acesso em: 29 set. 2008.
} 
eles nas questões sociais. A Igreja Católica, preocupada com as condições de pobreza dos trabalhadores e também com a influência dos comunistas sobre eles, começou a formular um pensamento social católico. O clero procurava construir uma alternativa para o socialismo e para o liberalismo econômico que era visto, também, como um mal e responsável pela penúria dos trabalhadores.

Em 1891, o Papa Leão XIII publicou a encíclica Rerum Novarum. A partir desta obra, a Igreja Católica começou a formular oficialmente sua Doutrina Social, que serviria de direção para a atuação do clero e dos católicos nas questões sociais. Leão XIII afirmava que pretendia vir em "auxílio dos homens das classes inferiores, atendendo a que eles estão, pela maior parte, numa situação de infortúnio e de miséria imerecida". O Papa constatava que "o que é vergonhoso e desumano é usar dos homens como de vis instrumentos de lucro, e não os estimar senão na proporção do vigor dos seus braços". Para o diagnóstico do problema, porém, Leão XIII colocava a solução nas mãos dos patrões, pois, a eles competia a responsabilidade pelos operários, garantindo-lhes "plena satisfação" nas condições materiais (Leão XIII, 1891, pp. 10-23).

O Papa Pio XI, ao comemorar os 40 anos da Rerum Novarum, lembrava que, em certas regiões do mundo, os trabalhadores ainda estavam relegados "à ínfima condição e sem a mínima esperança de se verem jamais senhores de um pedaço de terra; se não se empregam remédios oportunos e eficazes, ficarão perpetuamente na condição de proletários" (Pio XI, 1931, p. 39). No entanto, esse remédio tem que de ser "segundo os princípios de um são corporativismo, que reconheça e respeite os vários graus da hierarquia social" (Pio XI, 1937, p. 33). A Doutrina Social Católica defendida pelo clero era assistencialista, paternalista e propunha como solução para os problemas socioeconômicos, uma conciliação entre as classes. E isso era proposto também pela hierarquia brasileira. 
Alguns bispos paulistas pediam aos "cristãos abastados" iniciativas para a solução do flagelo social da tuberculose em nome "da piedade cristã em favor dos nossos queridos pobres e doentes" ("Pastoral Coletiva do Episcopado Paulista sobre alguns erros contra a fé e a moral", 1941, p. 898). Não contém nenhuma referência neste documento à responsabilidade do Estado perante o flagelo da população ou de melhorias na Saúde Pública; defende-se apenas a ajuda dos ricos aos mais pobres. Um manifesto assinado pelos principais bispos do Brasil, que deveria servir de orientação de conduta aos católicos, defendia como solução para os problemas sociais, a assistência, pois constitui:

"Quando bem organizada e aplicada, um elemento de desafogo de milhares criaturas que, de outra forma, nas circunstâncias presentes, não encontrariam outra maneira de reajustamento nem outros meios imediatos para atender às necessidades urgentes de sua vida, na defesa da saúde, da educação, da alimentação, da moradia e da higiene" ("Manifesto do Episcopado Brasileiro sobre a Ação Social", 1946, p. 479).

Estas manifestações do episcopado despolitizavam os problemas sociais. Os sacerdotes revelavam uma análise simplista da realidade brasileira e superestimavam o alcance real da assistência social, além de uma visão paternalista das relações sociais. A hierarquia não percebia que sem reformas que resolvessem as causas da pobreza, toda solução teria um alcance restrito. O clero via como causa dos problemas sociais menos as estruturas do que a falta de religiosidade da sociedade; os conflitos não estariam principalmente no sistema capitalista, mas sim nos corações dos homens. O Papa Pio XI questionava se não tinha sido a cobiça "que arrastou o mundo ao extremo que todos vemos e todos deploramos?” (Pio XI, 1932, p. 579). 


\section{Doutrina social católica e luta de classes}

Tanto nas declarações papais quanto nas da hierarquia brasileira existia uma condenação enfática da luta de classes. Em alguns momentos chegaram a afirmar que seria uma invenção dos comunistas para desestruturar a sociedade. $\mathrm{O}$ episcopado brasileiro avisava que:

"A luta de classe é abominável aos olhos de Deus porque divide os homens, sob o signo do ódio, da violência e da morte. O grande ideal cristão é que se chegue, pelo feliz encontro de soluções harmoniosas, a uma transformação social em que as riquezas se espalhem, em justo equilíbrio, por todos os homens que trabalham [...] é preciso que os homens, dirigidos e dirigentes, empregados e empregadores se tratem dentro do critério de respeito, dignidade, justiça e fraternidade" ("Manifesto do Episcopado Brasileiro sobre a Ação Social”, 1946, pp. 482-483).

A hierarquia católica estava preocupada em ajudar a formular soluções para os problemas sociais, mas ao negar a luta de classes, acabava por perceber as relações sociais de uma forma um tanto idílica. Colocava no mesmo patamar trabalhadores e patrões, acreditava piamente que os objetivos de ambos não necessariamente tinham de entrar em conflito. Ao invés de estimular os trabalhadores na luta por melhorias, pedia aos patrões que, por um dever moral, concedessem aos seus empregados um justo salário.

A solução para as questões sociais tinha de passar pela conciliação entre as classes que para o clero não seriam antagônicas. Isso fica latente quando lemos o estatuto da Federação Operária Cristã de Pernambuco que afirmava que sua função era: "Restabelecer a paz no mundo do trabalho, pelo respeito dos direitos de todos e pelo estabelecimento das mais cordiais e harmoniosas relações entre patrões e operários" (Souza, 1994, p. 17). Os jesuítas criaram um orga- 
nismo para trabalhar com os operários, em Fortaleza, no Ceará, chamado União Popular Cristo Rei que tinha como objetivo "criar harmonia baseada na justiça entre as classes de patrões e operários” (Azevedo, 1986, p. 236).

Então, nesse, como em outros pontos, entravam em choque o pensamento oficial da Igreja Católica e o comunismo. Por isso se torna necessário que se entenda o que significava classe para ambos. Não é pretensão fazer, aqui, uma análise dos vários estudiosos que se debruçaram sobre o significado de classe social, pois não é o espaço propício para isto. O que se quer salientar é a diferença existente entre uma noção de classe marxista e aquela mais corrente entre o clero, para então ficar claro o que cada um quer dizer quando fala da luta de classes.

Apesar de classe ser um conceito fundamental da obra de Karl Marx, ele nunca definiu explicitamente o que seria; mas podemos perceber alguns elementos do que significava

114 para ele. Classe social serve para identificar os agrupamentos que emergem da estrutura das desigualdades sociais. Para Marx, as classes são as expressões do modo de produzir de uma sociedade, mas o próprio modo de produção se define também pelas relações que intermedeiam as classes sociais e que dependem das relações das classes com os instrumentos de produção. Toda classe é sempre definida pelas relações que a ligam às outras classes, dependendo tais relações das diversas posições que as classes ocupam no processo produtivo. Ele lembra que: "os indivíduos isolados só formam uma Classe na medida em que têm de travar uma luta comum contra uma outra classe" (Marx e Engels, 1984, p. 83).

A luta de classes é o confronto - aberto ou dissimulado - que se produz entre classes antagônicas em favor de seus interesses enquanto classe. Os proprietários dos Meios de Produção querem explorar ao máximo os trabalhadores, pagando o menor salário possível; em contrapartida, os trabalhadores querem o inverso. E são esses interesses intrín- 
secos às classes antagônicas que fazem com que os marxistas afirmem que o Capital e o Trabalho não têm interesses comuns. A luta de classes não ocorre apenas no conflito aberto, ela está presente em todo momento das relações entre os proprietários dos Meios de Produção e os que têm que vender a sua força de trabalho.

A classe social para o clero fundamentava-se sobre uma concepção de mundo própria da Igreja Católica. A sociedade era vista como um Corpo harmonioso, cujas diversas partes deveriam cooperar em vista de um bem comum. As classes eram diversas, mas, não antagônicas; e deveriam se complementar para não enfraquecer o Todo. As classes, para esse pensamento social católico, eram diferenças hierárquicas entre grupos que sempre estiveram presentes na história da humanidade, por isso, que em alguns documentos, chegaram a afirmar que era "uma lei da natureza".

O clero entendia a sociedade como um Corpo Social, sendo cada classe, na verdade, membro deste Corpo. Por essa visão, cada membro (classe) tinha sua função e deveria colaborar em harmonia com os outros membros para o bem do Todo. Pois, como lembra Pio XI, a ordem "é a unidade resultante da disposição conveniente de muitas partes" e "o corpo social não será verdadeiramente ordenado, se não há um vínculo comum que una solidamente num só todos os membros que o constituem" (Pio XI, 1931, p. 49). Por esta concepção, patrão e empregado tinham, sim, os mesmos interesses: o bem-comum. E para que isso fosse alcançado, cada um tinha de fazer a sua parte. A função dos trabalhadores seria trabalhar e a dos proprietários zelar pelos seus empregados e cuidar dos negócios.

Em relação às desigualdades sociais, os Papas criticavam os comunistas, pois eles queriam acabar com as classes e tornar a sociedade igualitária, e isso, seria um atentado contra as leis naturais. Pio XI alertava que "erram vergonhosamente todos que sem consideração atribuem a todos os homens 
direitos iguais na sociedade civil e asseveram que não existe legítima hierarquia” (Pio XI, 1937, p. 34). Leão XIII já tinha lembrado muito tempo antes que a desigualdade "reverte em proveito de todos, tanto da sociedade como dos indivíduos; porque a vida social requer um organismo variado e funções muito diversas" (Leão XIII, 1891, p. 21). Em outras palavras, o indivíduo era operário ou patrão por um desígnio de Deus, e seria melhor para o operário continuar sendo operário, pois, ao tentar subverter sua condição, acabaria por levar à desarmonia do Todo.

Se a Doutrina Social da Igreja negava a luta de classes, uma vez que entendia a sociedade como Corpo Social, então era:

"Erro capital na questão presente crer que as duas classes são inimigas uma da outra, como se a natureza tivesse armado os ricos e os pobres para se combaterem mutuamente num duelo obstinado. Isto é uma aberração tal, que é necessário colocar a verdade numa doutrina contrariamente oposta, porque, assim como no corpo humano os membros, apesar de sua diversidade, se adaptam maravilhosamente uns aos outros, de modo que formam um todo [...] assim também, na sociedade, as duas classes estão destinadas pela natureza a unirem-se harmoniosamente" (Leão XIII, 1891, p. 22).

Com esta concepção de sociedade como um Corpo Social, a luta de classes acabava sendo percebida apenas como o conflito aberto, a pura violência entre os grupos hierárquicos; assim sendo, contrário ao amor evangélico. A Igreja Católica na prática acabava por defender uma doutrina paternalista e conservadora. Tentava controlar os movimentos de trabalhadores, desmobilizava grupos sociais que lutavam pela defesa de seus direitos e, muitas vezes, o clero acabou se aliando às classes dominantes contra os trabalhadores. Pode-se dizer que essa visão da sociedade foi hegemô- 
nica no clero, na primeira metade do século passado. Mas, a partir da década de 1950, e principalmente após o Concílio Vaticano II, a Igreja se abriu para o mundo e outro pensamento social começou a ser construído, na América Latina, principalmente com a Teologia da Libertação.

\section{Sinal de novos tempos: "do anátema ao diálogo"}

A partir das décadas de 1950 e 1960, ocorreram mudanças significativas na Igreja Católica, tanto em escala mundial quanto nacional. O mundo do pós- $2^{\text {a }}$ guerra não condizia com a atitude triunfalista e unilateral da Igreja. Em uma sociedade sob o espectro da Guerra-fria, o desenvolvimento tecnológico e bélico acentuados, a descolonização da Ásia e da África, o aumento da influência que os partidos Comunistas começaram a ter nos países europeus e em outros continentes, além do impacto perturbador da Revolução Cubana, a visão fechada e estática da Igreja foi perdendo terreno. Com o acirramento e a politização dos conflitos sociais, principalmente na América Latina, essa concepção de Corpo Social começava a perder força para vários setores católicos. A Igreja Católica iniciava o seu aggiornamento; e com a eleição de João XXIII e o Concílio Vaticano II essa atualização foi impulsionada.

O Concílio enfatizou a missão social da Igreja Católica, defendeu a importância do laicato dentro da instituição, valorizou o diálogo ecumênico, modificou a liturgia para torná-la mais acessível e desenvolveu a noção de Igreja como povo de Deus. Substituiu a ideia de Igreja como mestra do mundo pela de serva do mundo. O padre José Oscar Beozzo afirmou que:

"João XXIII e, de modo particular, o Concílio foram para a Igreja do Brasil como se águas longamente represadas se houvessem soltado, correndo livremente, abrindo e aprofundando o próprio leito" (Beozzo, 1993, p. 11). 
A constituição pastoral do Concílio Vaticano II, Gaudium et Spes, demonstrava claramente a abertura da Igreja Católica ao mundo moderno e a procura de um diálogo da hierarquia com os setores antes desprezados na intenção da construção de um mundo melhor.

"Ainda que rejeite inteiramente o ateísmo, todavia a Igreja proclama sinceramente que todos os homens, crentes e não crentes, devem contribuir para a reta construção do mundo no qual vivem em comum. O que não é possível sem um prudente e sincero diálogo" (“Gaudium es Spes”, 1966, p. 28).

Estava aberta a porta para um diálogo mais intenso entre os setores católicos mais progressistas e os segmentos da sociedade que lutavam por uma transformação social, em especial, os comunistas. E o diálogo seria bem-vindo para alguns comunistas como mostra o então marxista Roger

118 Garaudy, que afirmou:

"O futuro do homem não poderá ser construído nem contra os crentes, nem tampouco sem eles; o futuro do homem não poderá ser construído nem contra os comunistas, nem mesmo sem eles" (Garaudy, 1966, p. 10).

No entanto, pelo menos desde a década de 1950, alguns teólogos franceses já estavam estimulando esse diálogo com o marxismo e influenciaram importantes segmentos da Igreja Católica no Brasil. ${ }^{2}$ O jesuíta francês Jean-Yves Calvez publicou $O$ pensamento de Karl Marx, no qual promoveu um diálogo crítico com Marx e os marxistas, e que influenciou vários segmentos católicos. Apesar das duras críticas de JeanYves Calvez a Marx e aos seus seguidores, Calvez despertou

\footnotetext{
${ }^{2}$ Pensadores católicos, a exemplo de Lebret, Emmanuel Mounier, Thomas Cardonnel, entre outros, tiveram influência principalmente nos setores ligados à Ação Católica Brasileira. Ver Löwy (2000, pp. 230-245).
} 
alguns inacianos e leigos para um maior conhecimento da obra do pensador alemão, como nos mostra o depoimento de Hebert de Souza, o Betinho:

"Lemos Marx através de Yves Calvez [...] Nossa leitura de Marx, via Yves Calvez, era no fundo uma busca de conciliação, uma forma de resgatar no Marx que desconhecíamos um Marx que pudéssemos conhecer sem negar o que éramos, e éramos cristãos" (Palácio, 1982, p. 19).

Esse diálogo entre os comunistas e católicos teve seu início no continente europeu. Porém, nesse momento, foi um diálogo com muita cautela e certas desconfianças de ambas as partes, como está claro no livro organizado por Mário Gozzini, Diálogo posto à prova, em que católicos e comunistas italianos debatiam as possibilidades e limites desse encontro. O intelectual católico Ruggero Orfei afirmava categoricamente que "o cristão não pode ser comunista" por existir uma fratura irremediável entre ambos, e fazia severas críticas ao comunismo; porém, defendia o diálogo e a aceitação "de homens que discordam de nós e até mesmo que nos combatem [...] como um sinal da Providência a ser compreendido e interpretado" (Orfei, 1968, pp. 177-191).

O comunista italiano Lúcio Lombardo Radice afirmava que apesar de colocar de lado qualquer hipótese de conciliabilidade filosófica entre cristãos e comunistas, ele percebia que existia também uma carga revolucionária dentro da fé religiosa; então, o autor demonstrava perceber que esse diálogo poderia ser muito frutífero para ambas as partes. E sobre o caráter essencialmente reacionário das religiões defendido por alguns marxistas, ele lembrava Marx que afirmou que "é o homem que faz a religião, e não a religião que faz o homem”, portanto, para um marxista não dogmático "uma religião é como os crentes a fazem, e por isto não é por definição, a priori, nem conservadora nem revolucionária” (Radice, 1968, p. 76). 
No Brasil, esse debate esteve presente em algumas publicações voltadas para os cristãos. Na revista Paz e Terra existem inúmeros artigos de pensadores europeus e brasileiros que analisaram esse diálogo de muitas maneiras. Para todos os autores era certeza de que na segunda metade do século XX, a convergência de posições entre marxismo e cristianismo surgia como um dos fenômenos mais interessantes do período.

Para Michel Verret, o diálogo entre marxistas e católicos foi imposto pela realidade histórica, pela vida e, por isso,

"queremos abordá-lo sob o ângulo da vida: não pelas ideias que nos separam (Deus), mas pela terra que nos é comum, pelos homens que, embora com crenças e sinais diferentes, têm que enfrentar os mesmos problemas" (1966, pp. 163-179).

E apesar de constatar que tradicionalmente a religião 120 tinha sido uma forma de dominação, uma força reacionária, ele percebia que isso estava de alguma forma mudando naquele momento histórico e que muitos católicos, agora, lutavam pela transformação no mundo: "E é preciso mudálo, porque não vai bem, nem para os homens, nem - imagino - para Deus" (Verret, 1966, pp. 163-179).

Paul Lehmann, em seu artigo intitulado Ética cristã - Ética marxista, enumerava as semelhanças entre a filosofia cristã e a marxista. O autor afirmava que "o que é comum ao cristianismo e ao marxismo é a convicção de que a libertação do homem realizar-se-á messianicamente" (1966, pp. 156-157). E, segundo ele, "no marxismo, como já sabem, este papel messiânico será exercido pelo proletariado. No cristianismo, será exercido na e através do pacto na comunidade cristã" (Lehmann, 1966, pp. 156-157). Por isso, poderia ocorrer um diálogo verdadeiro já que essas duas filosofias têm muito em comum; e partindo deste ponto, corroborava o que Luiz Maranhão escreveu para os marxistas brasileiros 
"Já não se trata de estender-lhes a mão [aos católicos], mas de marcharmos juntos com eles" (Maranhão, 1968, p. 71).

Em 1961, foi criada no Brasil a Ação Popular (AP), organismo nascido no interior da JUC e que congregou estudantes católicos que lutavam pela transformação social no país. A AP se destacou no cenário político daquele momento tendo uma influência decisiva na UNE durante a década de 1960. A Ação Popular se relacionava com os partidos comunistas e demonstrou profundas afinidades com o pensamento marxista. Este organismo foi muito influenciado pelo jesuíta Henrique Cláudio de Lima Vaz que é considerado como teórico e um dos principais inspiradores da AP no seu nascedouro. Este inaciano foi também um dos primeiros jesuítas a promover um debate com o marxismo no Brasil (Palácio, 1982).

Contudo, vários setores católicos criticaram essa aproximação que estava ocorrendo entre os católicos e comunistas nesse momento. O jesuíta italiano Ulisse Alessio Floridi escreveu um livro chamado $O$ radicalismo católico brasileiro que se tornou referência dos segmentos contrários a essa aproximação. O autor criticava os vários setores católicos brasileiros (religiosos e leigos) que estavam propondo uma colaboração com os comunistas no intuito de transformar a sociedade brasileira. Floridi afirmou que estava impressionado que, no Brasil, "leigos e eclesiásticos católicos sigam um Evangelho segundo Fidel Castro" (Floridi, 1973, p. 59).

Durante a década de 1950, principalmente no governo de Juscelino Kubitschek, o Brasil passou por uma industrialização acelerada, modernizando-se rapidamente. Porém, o governo de Kubitschek não enfrentou eficazmente os problemas sociais e sua política econômica propiciou uma acentuada concentração de renda e um aumento nas desigualdades entre as regiões mais ricas e as mais pobres. Os frutos do desenvolvimento foram colhidos por uma parcela minoritária da população, agravando-se as desigualdades e ocasionando o aumento das tensões sociais. 
Setores do clero, que tinham apoiado o desenvolvimentismo de JK, começavam a se tornar cada vez mais críticos ao Sistema, percebiam que o desenvolvimento da Nação, não necessariamente resolveria os problemas sociais. Declarações como a do bispo D. José Távora demonstravam isso claramente: "Um perigo maior que o comunismo ameaça o mundo. O responsável por isso é o regime capitalista” (Prandini et al., 1986, p. 71). Em um importante documento da CNBB, o episcopado fazia mea-culpa:
"Somos solícitos no combate ao Comunismo, mas nem sempre assumimos a mesma atitude diante do capitalismo liberal. Sabemos ver a ditadura do Estado marxista, mas nem sempre sentimos a ditadura esmagadora do econômico ou do egoísmo nas estruturas atuais que esterilizam nossos esforços de cristianização" (CNBB, 1963, p. 23 - grifos no original).

\section{Ceas e o marxismo}

Como foi afirmado anteriormente, este diálogo entre católicos e comunistas começou na Europa, mas foi na América Latina onde se produziram as alianças mais significativas entre os comunistas e os cristãos. No Chile, a Esquerda Católica foi um importante elemento no governo de Salvador Allende, como também na revolução nicaraguense e em El Salvador, onde os cristãos (incluindo vários jesuítas) desempenharam um papel essencial. Na Colômbia, o padre Camilo Torres foi morto após aderir à luta armada, ingressando no Exército de Libertação Nacional (ELN), combatendo pela revolução em seu país. Em 1972, aconteceu o "Primeiro Encontro LatinoAmericano de Cristãos para o Socialismo", no Chile, que procurou fazer uma síntese do marxismo e cristianismo no continente latino-americano e foi influenciado pelo jesuíta Gonzalo Arroyo. 
Foi também na América Latina que se operaram as transformações mais importantes dentro do pensamento católico, principalmente na Teologia da Libertação, movimento que surgiu durante a década de 1970 e que fez uma nova interpretação dos Evangelhos a partir dos problemas sociais do continente. Considerada como a primeira teologia a nascer no terceiro mundo, por isso sempre esteve muito mais preocupada com os problemas colocados pela miséria e exploração da população latino-americana. A Teologia da Libertação acentua a reflexão teológica com o sentido do compromisso dos cristãos com a justiça e a libertação dos povos (Boff, 1996).

Durante os anos 1970, alguns países da América Latina passaram por um processo de industrialização acelerada, mas ocorreu também um aumento da dependência em relação aos países centrais do capitalismo. A miséria e a pobreza acentuaram-se, enquanto a dívida externa aumentava. Os camponeses foram expulsos das terras que seriam utilizadas na agricultura de exportação, acarretando a favelização das grandes metrópoles. Além disso, vários países estavam vivendo em sangrentas ditaduras militares com o extermínio e desaparecimento de militantes de esquerda. A repressão chegava também ao clero e aos movimentos católicos que lutavam por uma transformação social. Foi nesse contexto que surgiu a Teologia da Libertação.

É comum afirmar que os teólogos da libertação fizeram uma opção pelos pobres. Mas o que importa saber é o significado desta opção. A relação com as classes populares não deveria passar pela caridade, pela doação de esmolas para as camadas mais carentes da população, como certos setores da Igreja Católica (e de outras Igrejas) faziam. Eles romperam com essa atitude assistencialista e lutavam para que os chamados pobres ou excluídos não necessitassem de esmolas ou caridade (e para isso era necessário transformar o Sistema) e lembravam que as classes populares eram as 
construtoras de sua própria libertação. Não se pregava uma assistência paternalista, e sim, uma atitude de união com a luta dos pobres pela sua autoemancipação.

O teólogo espanhol José Ramos Regidor afirma que a originalidade da Teologia da Libertação não seria a opção pelos pobres (com toda a razão, ele lembra que isso é uma característica da tradição católica), mas, sim, o reconhecimento das classes populares como sujeitos históricos em uma dupla dimensão: "sujeitos históricos na sociedade, capazes de autodeterminação e protagonismo na luta pela própria libertação”, porém, também o reconhecimento como sujeitos históricos dentro da Igreja na "produção de evangelização e de teologia" (Regidor, 1996, p. 30).

Essa teologia latino-americana recorreu às ciências sociais para auxiliar na análise da realidade latino-americana, e, em especial, ao marxismo. Os teólogos da libertação

124 reinterpretaram o marxismo de acordo com sua visão cristã e também com sua experiência social, adaptando-o à sua realidade. Segundo o marxista Michael Löwy, o uso do marxismo pelos católicos progressistas para analisar a realidade latino-americana deveu-se ao seguinte motivo:

"Essa descoberta do marxismo pelos cristãos progressistas e pela teologia da libertação não foi um processo meramente intelectual ou acadêmico. Seu ponto de partida foi um fato inevitável, uma realidade brutal e geral na América Latina: a pobreza. Para muitos fiéis preocupados com o social, o marxismo foi escolhido porque parecia ser a explicação mais sistemática, coerente e global das causas para essa pobreza, e a única proposta suficientemente radical para aboli-la" (Löwy, 2000, p. 123).

Este diálogo entre o catolicismo e o marxismo esteve presente também no Centro de Estudos e Ação Social 
(Ceas), uma instituição fundada pelos jesuítas na Bahia. ${ }^{3}$ Na sua revista - Cadernos do Ceas -, podemos claramente perceber como os leigos católicos e os inacianos do Centro de Estudos e Ação Social reinterpretaram o marxismo com base na sua tradição católica.

Os religiosos e leigos do Ceas também fizeram $a$ opção pelos pobres e procuraram auxiliar as classes populares na sua libertação. Como lembrava o teólogo e ex-coordenador do Centro Social, Cláudio Perani, "o conhecimento de Deus deve estar ligado à causa concreta da libertação” já que “não é possível crer no Deus libertador sem participar no processo de libertação" (Perani, 1980, p. 66). Mas esse contato com as bases tinha de sempre levar em conta que os pobres eram os responsáveis por sua libertação, eles não precisavam de um partido ou intelectuais que decidissem por eles. Paulo Cezar Lisboa, no encontro das obras sociais da Companhia de Jesus, em Salvador, avisava que os membros do Ceas não tinham

"uma proposta definida e precisa da sociedade, nem um modelo já pronto. Apenas acreditamos que, seja qual for esse projeto, ele só será válido e exequível se contar sempre com a participação crítica e autônoma do povo" (Ceas, 1993, p. 62).

Segundo os documentos produzidos pelos membros do Centro Social, o marxismo serviria para desmascarar a realidade e os tornarem mais conscientes das estruturas e das

\footnotetext{
${ }^{3}$ A partir do Pós-2. ${ }^{a}$ Guerra Mundial, os jesuítas começaram a priorizar em seu trabalho apostólico as questões sociais. Um instrumento adotado pela Companhia de Jesus para enfrentar os problemas sociais nesse período foram os Centros de Informação e Ação Social (Cias). Esses Centros tinham como objetivo difundir a Doutrina Social da Igreja e também ser um local de reflexão sobre as questões socioeconômicas de um determinado lugar e que tentava ajudar os jesuítas (e a sociedade) na superação dos problemas apontando as causas e mostrando os meios para isso. Em Salvador, foi fundado, na década de 1960, o Centro de Estudos e Ação Social (Ceas) pelos jesuítas que formavam a vice-província da Bahia. (Zachariadhes, 2009).
} 
causas da pobreza. Em um encontro dos jesuítas, em que o então padre Tomás Cavazzuti participou representando o Ceas, ele afirmou que "parece ter importância especial o uso da análise científica da sociedade formulada pelo marxismo, para manter o senso crítico diante das ideologias, da realidade social e da práxis histórica". 4

O documento "Entidade Ceas" (dezembro 1976) assegurava que o trabalho do Ceas estava "visando à transformação social". E se entendermos o marxismo como filosofia da práxis, ou seja, como a produção de um conhecimento para a transformação da realidade, perceberemos melhor a sua influência dentro desse pensamento católico. Pois o que importava não era "conhecer a verdade da história e da sociedade, mas a de transformar a realidade para que se torne mais humana” (Ceas, 1982, p. 57). Teoria e práxis se completavam dialeticamente, pois toda ação necessitava de uma teoria que só se validava na prática.

$126 \quad$ Nos cadernos do Ceas de número 7, de junho de 1970, era transcrito o texto do jesuíta Oswald Von Nell Breuning Igreja católica e crítica marxiana do capitalismo, que afirmava ter Marx tornado os cristãos mais conscientes de que:

"as estruturas sociais concretas não devem ser aceitas assim como se apresentam, como se fossem estruturas naturais; estas não são [...] categorias 'eternas' elas, muito mais do que um 'dado', são um problema” (Nell-Breuning, 1970, p. 9).

A pobreza não era uma fatalidade divina, mas resultado de um Sistema perverso, e o marxismo ajudou os católicos progressistas a perceberem os problemas estruturais da sociedade capitalista e tornou-os mais cientes de que a realidade social não era inexorável, era histórica; assim sendo, poderia ser transformada.

${ }^{4}$ Encontro Latino-Americano dos jesuítas no Social, 15-22/07/1974. (Arquivo do Ceas). 
Friedrich Engels no seu trabalho Contribuição para a história do cristianismo primitivo afirmava que entre o cristianismo primitivo e o Movimento operário de sua época havia em comum que ambos pregavam a libertação, mas "o cristianismo transpõe essa libertação para o além, numa vida depois da morte, no céu" (Engels, 1972, p. 353). Porém, isso não era mais válido nem para o pensamento defendido pelo Ceas nem para alguns bispos e Superiores de Ordens religiosas do Nordeste, que afirmaram:

"A salvação não se configura, portanto como realidade fora do mundo, a ser alcançada apenas na trans-história, na vida de além-túmulo [...] Ela começa a efetuar-se aqui" ("Eu ouvi os clamores do meu povo", 1973a, p. 57).

Evidentemente que eles não negavam a importância da salvação espiritual; o que eles defendiam era que a luta pela salvação tinha de começar em vida e na vida.

O Ceas sempre foi muito criticado por alguns setores católicos pelo diálogo que promoveu com o marxismo. Por isso, foi de grande importância para os religiosos e leigos desta instituição a declaração do Prepósito Geral da Companhia de Jesus, Pedro Arrupe, no seu documento Análise Marxista, de 8 de dezembro de 1980, que era endereçado aos Superiores maiores da América Latina. Segundo Arrupe, muitos jesuítas pediam a sua posição na questão sobre a análise marxista. E esse texto tinha como finalidade principal responder à seguinte pergunta: "Pode um cristão, um jesuíta, utilizar a 'análise marxista', distinguindo-a da filosofia ou ideologia marxista, e também da práxis ou, pelo menos, de sua totalidade?".

Como todos os documentos da alta hierarquia da Igreja Católica que abordam temas polêmicos, este texto é muito cauteloso nas suas considerações. Primeiramente, é necessário ressaltar que Pedro Arrupe demonstrou certo conhe- 
cimento do marxismo ou como ele mesmo fez questão de salientar: "marxismos". Ele lembrava aos cristãos que não existia apenas uma análise social marxista já que o marxismo estava ligado a uma práxis.

Ele criticou a análise marxista pelo seu sentido redutor, já que a política, a cultura e a religião perdiam sua própria consistência e se tornavam redutíveis à esfera do econômico. Naturalmente, criticou da mesma forma a postura em relação à religião e ao que ele chamou de esvaziamento do aspecto "transcendental do cristianismo". O Superior da Companhia de Jesus também fez ressalvas à posição de Marx em relação à propriedade. Contudo, ele fez questão de frisar que as análises sociais do mundo liberal implicavam "em uma visão materialista e individualista do mundo, que é também oposta aos valores e atitudes cristãos” e perguntava: "Não temos notado com frequência formas de anticomunismo que não passam de meios para encobrir a injustiça?”.

128 Pedro Arrupe afirmou que aceitava certo número de pontos metodológicos que surgiram da análise marxista (desde que não se desse caráter exclusivo a eles). O Prepósito asseverou que a atenção para os fatores econômicos, para as estruturas de propriedade, os interesses econômicos que podiam mover os grupos, a sensibilidade à exploração de certas classes, a atenção que ocupava a luta de classes na história de numerosas sociedades e o cuidado com certas ideologias que podiam servir de disfarces às injustiças, eram tributários ao marxismo. O Padre ainda afirmou que as críticas dos marxistas serviram para abrir os olhos em relação aos casos em que a religião encobria situações sociais indefensáveis. Então, apesar de algumas ressalvas, ele ratificou: "devemos nos manter sempre dispostos ao diálogo, no que concerne aos marxistas" (Arrupe, 1981, pp. 5-13).

\footnotetext{
${ }^{5}$ No editorial do caderno 73, esse documento foi comentado. Os membros do Ceas afirmavam que "o caminho concreto dos compromissos vividos parece ser o melhor caminho para a Igreja avançar juntamente com o povo guardando fideli-
} 


\section{Ceas: um novo pensamento social católico}

No pensamento social formulado pelo Ceas, quando se falava em classe, era no sentido marxista do termo que se colocava. No texto Marxismo, cristianismo e luta de classes, Rafael Belda criticou o sentido dado pela Doutrina Social Católica tradicional à classe, pois, segundo ele, "não captou o sentido exato do antagonismo objetivo entre as classes, em parte por dar ao termo classe um sentido impróprio" já que não percebia "claramente os aspectos estruturais dos problemas morais" (Belda, 1979, p. 62). O antagonismo entre as classes era fruto das desigualdades da sociedade capitalista e a exploração sofrida pelos trabalhadores era estrutural e, não, moral.

Os membros do Ceas chegaram a definir nos Cadernos o que significava classe para eles. É de ressaltar a importância dada à esfera econômica para o indivíduo ou camada social. Nessa definição, classe é o:

"Lugar que cada indivíduo ou camada social ocupa na

produção e distribuição dos bens econômicos. Cultura, prestígio, funções sociais e políticas, status, profissão, vinculam-se, direta ou indiretamente, à situação econômica" (Ceas, 1972, p. 28).

Talvez a influência mais importante do marxismo no Ceas tenha sido a incorporação da luta de classes no pensamento social católico. E esse ponto faz-se necessário realçar, pois é preciso deixar claro que a práxis do Ceas era orientada por esta certeza: na sociedade capitalista existiam classes com interesses opostos (e não complementares como defendia o Magistério social tradicional da Igreja) que entravam em conflitos constantes, já que, "a luta de classes é um fato objetivo, derivante da contraposição necessária entre explo-

dade ao Evangelho e apreciando criticamente, mas sem medo ou preconceito, as ideias novas" (Ceas, 1981, p. 6). 
rados e exploradores, característica do sistema capitalista" (Ceas, 1973b, p. 41).

Os membros do Ceas divergiam da Doutrina Social tradicional da Igreja que percebia a luta de classes como algo artificial para a sociedade, e quando alguém se referia à luta de classes, era como se estivesse pregando, na verdade, o ódio entre os homens; assim sendo, iria de encontro ao amor pregado por Cristo. Isto para os membros do Centro Social seria, na verdade, uma tendência moralizante de setores católicos que não conseguiam ver os problemas na estrutura e se prendiam apenas no indivíduo. Olhando por esse prisma, o problema não estaria na sociedade e, sim, na conduta dos homens. E, ao invés de se lutar por uma transformação social, pedia-se que o opressor percebesse a sua opressão e ajudasse o oprimido por um dever moral. Esta era a crítica feita pelo jesuíta Cláudio Perani, uma vez que isto apenas era uma maneira de "levar o rico a ajudar 130 alguns pobres, deixando estes últimos numa situação de maior dependência e na mesma ou maior pobreza" (Perani, 1977, p. 52).

O texto Luta de classes e comunhão cristã de Gerard Fourez é representativo desta crítica ao pensamento tradicional dos católicos. Para Fourez, os cristãos por não compreenderem a luta de classes não a identificavam com a comunhão cristã; mas ele avisava que não se vivia "concretamente o Evangelho no mundo de hoje sem viver, ao mesmo tempo, a luta de classes". Ele logo advertia que a luta de classes só era percebida como ódio entre os homens se fosse vista num sentido individualizante, ou seja, que se excluíssem as estruturas. Por isso, ele lembrava que "falar em luta de classes é, portanto, reconhecer que as pessoas, na realidade não são iguais" e esta desigualdade acabava se traduzindo em “opressão que aliena”. Por isso mesmo, ele ratificava que falar em luta de classes "não é criar a divisão, é reconhecer sua existência” (Fourez, 1975, pp. 41-43). 
Neste ponto, podemos verificar como era difícil para setores da Igreja Católica, religiosos e leigos, aceitar a luta de classes, pois ainda se prendiam ao sentido tradicional dado pela Doutrina Social. Para esses setores, quando os teólogos da libertação falavam em luta de classes era como se eles quisessem dividir a sociedade, como se eles quisessem criar o conflito entre os homens (como se o conflito já não existisse). Isso era tão forte no pensamento católico que o teólogo Gustavo Gutierrez, no seu clássico Teologia da Libertação, teve de ressaltar:

"Reconhecer a existência da luta de classes não depende de nossas opções éticas ou religiosas. Há os que tentam considerá-la algo artificial, estranho às normas que regem nossa sociedade [...] A luta de classes não é produto de mentes fabricantes senão para quem não conhece ou não quer conhecer o que produz o sistema [...]. Aquele que fala de luta de classes não a propugna - como se ouve dizer - no sentido de criá-la de início por um ato de (má) vontade; o que faz é provar um fato, e no máximo contribuir para que dele se tome consciência" (Gutiérrez, 1979, p. 228).

Os membros do Ceas, ao perceberem na sociedade a luta de classes, passaram a enxergar a realidade brasileira como “dividida em classes com interesses contraditórios" e, sendo assim, negava-se qualquer possibilidade de união entre Capital e Trabalho, de conciliação entre as classes, já que os interesses de ambos eram excludentes. E partindo deste ponto, pregava-se uma atitude firme, já que "não existe uma opção de meio termo: a opção ou é radicalmente pelo oprimido ou é radicalmente pelo opressor" (Ceas, 1971a, pp. 4-5).

Pode-se argumentar que era simplista dividir a sociedade em oprimido e opressor. Evidente que essa mera divisão não dava conta da complexidade da sociedade. Mas a 
questão mais importante não é esta. O fundamental é que no momento em que os membros do Ceas perceberam a opressão da estrutura classista e que as classes tinham interesses contraditórios, a prática deles com as classes populares tornou-se qualitativamente diferente da de outros setores católicos que trabalhavam também com as bases. Ao assumirem que o Trabalho e o Capital tinham interesses contraditórios, a solução nunca passaria pela conciliação de classes, fazendo com que ao invés de se ter uma atitude assistencialista e paternalista com o povo, se lutasse pela transformação social.

Se, como já foi dito, a estrutura classista era um problema, pois oprimia a maioria da população e a libertação do homem tinha que ocorrer na história, não é de se estranhar quando se lê no Caderno 64, que

"o projeto de uma sociedade sem classes concorda com a inspiração fundamental do Evangelho, que é a construção de uma sociedade humana, baseada na comum fraternidade divina" (Belda, 1979, p. 63).

Ou como afirmou Tomás Cavazzutti, a sociedade de classes é "anticristã", por isso "as classes devem ser suprimidas” (Cavazzutti, 1984, p. 78). Então, o Reino de Cristo na terra só seria possível em uma sociedade aclassista. E neste ponto o pensamento do Ceas inovava tanto em relação ao catolicismo quanto ao marxismo, fazendo, na verdade, uma amálgama dos dois.

Como já foi demonstrado, para o Magistério Social da Igreja Católica, as classes eram percebidas sem problemas; os Papas chegaram a criticar os comunistas por defenderem uma sociedade aclassista. As classes eram divisões hierárquicas que sempre existiram na história humana; por isso, em alguns documentos, afirmam ser uma lei da natureza. Agora, em relação ao marxismo, este sempre defendeu como fim 
último, uma sociedade sem classes. Porém, para vários setores, nessa sociedade aclassista não seria necessária a religião. $\mathrm{E}$ isso também foi defendido pelo pensamento marxiano.

No seu trabalho Crítica da filosofia do direito de Hegel, Karl Marx criticava Hegel, pois ele não tinha percebido na gênese da superestrutura as condições materiais. A religião só existiria porque os homens se encontravam perdidos; o sentimento religioso era entendido como um fruto da alienação na sociedade capitalista; assim sendo, "a abolição da religião enquanto felicidade ilusória do povo é uma exigência que a felicidade real formula". Podemos afirmar que para Marx, quando o homem não estiver mais alienado pelo trabalho (em uma sociedade sem classes), o fenômeno religioso não terá mais sentido, pois "a religião não passa do sol ilusório que gravita em volta do homem enquanto o homem não gravita em volta de si próprio" (Marx, 1972, pp. 44-47).

Devemos lembrar que Marx viveu no século XIX, então, como um homem de seu tempo está refletindo em uma realidade histórica definida. Porém, ainda na segunda metade do século XX, alguns setores marxistas continuavam defendendo essa ideia. No texto Marxismo e Cristianismo do filósofo Leandro Konder, ele percebia uma evolução do clero católico para posições mais progressistas e se surpreendia com alguns documentos da Igreja brasileira, por isso, defendia o diálogo entre comunistas e católicos de esquerda. Ele avisava, entretanto, desde que a religião não venha a ser canalizada para a repressão, para um marxista era

"absurdo pretender promover uma superação da ideologia religiosa sem que tenha sido anteriormente criado o mundo que, em principio pode vir a tornar desnecessária tal ideologia" (Konder, 1978, p. 65).

O mundo em que a ideologia religiosa seria desnecessária era uma sociedade aclassista. 
Enquanto os Papas defendiam uma sociedade classista, alguns marxistas afirmavam que em uma sociedade sem classes a religião não seria necessária. O Centro Social percorria uma nova vertente na qual defendia que era justamente em uma sociedade sem classes que se começaria a ser preparado o Reino de Cristo na Terra. Mas uma pergunta se faz necessária: como chegar a essa sociedade sem classes? A questão não era fácil de ser respondida e nem eles tinham a pretensão de oferecer fórmulas, mas o que eles sabiam era que "a solução não será oferecida pela classe dominante, ela será arrancada; não será uma solução concordata, mas conflitual" (Girardi, 1972, p. 53).

O Ceas legitimava o uso da violência do oprimido contra o opressor na luta pela sua emancipação. Para os padres e leigos, se as classes dominantes para continuarem no poder utilizavam a força para oprimirem as classes populares, não era nenhum ato antievangélico a violência do opri-

134 mido para se libertar, pois

"a experiência histórica mostra que a classe privilegiada nunca renuncia espontaneamente às suas posições de poder, mas sempre unicamente por ser vencida por uma força maior" (Ceas, 1973b, p. 45).

É necessário, entretanto, salientar que o uso da violência era legitimado, mas com muita cautela pelo Ceas. O uso da força pelos cristãos tinha que obedecer a um código de ética, pois "não se pode aceitar o uso indiscriminado da violência, a manipulação de pessoas, o proselitismo fundado na calúnia ou na mentira” (Belda, 1979, p. 64). A violência nunca era um fim em si mesmo. A força e o derramamento de sangue só eram lícitos em situações extremas e em momentos históricos próprios, pois "é necessário evitar que os oprimidos de hoje se tornem os opressores de amanhã" (Ceas, 1973b, p. 45). 
Pode parecer contraditório para alguns, porém, a violência praticada pelas classes populares contra os opressores na luta pela sua emancipação era um sinal de Amor. As pessoas que estranham esta afirmação estariam tendo, segundo os membros do Ceas, uma visão individualizante. Percebem o amor apenas na dimensão entre os indivíduos; porém, o Amor por eles pregado era um amor social, ou seja, "uma atitude que respeita, valoriza e promove o bem comunitário" (Ceas, 1971b, p. 52). O Amor não negava ou escondia o conflito na sociedade, ao contrário, revelava; e chamava o cristão para enfrentá-lo, para superar as divisões com "eventual violência" se preciso fosse, pois, como afirmou o padre Cláudio Perani:

"É necessário redescobrir as dimensões sociais e políticas da teologia do amor; reconhecer que o amor é revolucionário e deve assumir os conflitos. Sem uma certa luta, um determinado esforço, nunca se alcançará superar a sociedade dividida em classes. Negar a luta de classes pode significar o oposto do que pretende a reconciliação cristã, porque seria ratificar uma situação de divisões" (Perani, 1977, p. 59 - grifos no original).

Um ponto em que o Ceas defendia a mesma concepção da Doutrina Social Católica tradicional era em relação à propriedade privada. Para ficar mais claro o que está sendo expresso aqui, é necessário analisar a encíclica de Paulo VI, Populorum Progressio, de 1967. O Papa defendia nesse documento, um desenvolvimento integral do homem, colocava a culpa da pobreza dos países periféricos na exploração dos países centrais, criticava o capitalismo liberal e em relação à propriedade privada afirmava:

"Deus destinou a terra e tudo o que nela existe ao uso de todos os homens e de todos os povos [...] Todos os outros 
direitos, quaisquer que sejam, incluindo os de propriedade e de comércio livre, estão-lhe subordinados [...] Quer dizer que a propriedade privada não constitui para ninguém um direito incondicional e absoluto [...] o direito de propriedade nunca deve exerce-se em detrimento do bem comum" (Paulo VI, 1967, pp. 21-22 - grifos meus).

É preciso reconhecer que os Papas sempre defenderam a propriedade privada, mas nunca deram a ela um direito absoluto. Tanto Paulo VI como seus predecessores defendiam a propriedade privada, desde que não infligisse o bem comum. O Superior Geral da Companhia de Jesus, Pedro Arrupe, também advogava o mesmo ponto de vista. Arrupe reafirmava "o direito de cada individuo de possuir o que é necessário para si e para a sua família”, mas recordava "que a Igreja não mantém nem manteve nunca que o direito de propriedade seja absoluto e sem condições" (Arrupe, 1976, p. 16).

136 Essa posição com relação à propriedade privada também era defendida pelo Centro Social. No documento Centro de Estudos e Ação Social - Princípios e orientações - 1968, eles quase repetiam o Papa, afirmando que "o direito de propriedade nunca deve exercer-se em detrimento da utilidade comum". Para ficar mais claro este ponto, será analisado o texto Algumas considerações doutrinárias sobre propriedade e justiça, publicado nos cadernos do Ceas, número 12, que é representativo do pensamento da instituição.

O texto lembrava que o que se queria tratar evidentemente era da propriedade privada dos Meios de Produção e não da propriedade dos bens de consumo, como roupas, aparelhos, instrumentos pessoais, comida entre outros. $\mathrm{O}$ bem de consumo era exclusivo já que "pertence por sua natureza a uma pessoa particular". Depois de feito este parêntese, o texto afirmava que pela Doutrina Social Católica, a propriedade privada dos Meios de Produção era um direito natural, e afirmava que a Igreja "defende a proprie- 
dade privada [...] porque ela acha que é uma condição indispensável para a liberdade da pessoa humana”. Mas, lembrava do caráter "intrinsecamente relativo da propriedade privada".

Esse caráter relativo da propriedade privada se fundamentava no que o texto chamou de direito de propriedade $\mathrm{e}$ direito de uso. $\mathrm{O}$ homem realizava sua natureza na propriedade, então era um direito dele possuir bens. Mas a propriedade tinha um caráter intrinsecamente social, ou seja, a destinação dos bens era para todos. A terra poderia ter um dono (direito de propriedade), porém a produção era social (direito de uso). Assim sendo, "diante do direito de uso o direito de propriedade deve ceder completamente". Por isso era tão absurda para o clero a visão liberal, pois a propriedade não tinha nenhuma limitação, ela se tornava absoluta; assim "não é mais o homem que possui, mas é ele que é possuído pelas coisas”.

O texto criticava também os países comunistas que em suas estruturas não excluem a possibilidade de dirigentes de empresas abusarem de seu poder em favor dos próprios interesses. Então, "a única solução real é, pois a propriedade relativa, controlada, limitada". Limitada por quem? Deve ser controlada pela autoridade pública e também pela responsabilidade da consciência dos indivíduos. Eles salientavam este segundo ponto já que era "o individuo que deve decidir dentro de sua consciência o que vai fazer com sua propriedade". Pois, o direito de propriedade significava "o direito de tomar decisões em relação aos bens possuídos, respeitando sua destinação comunitária”. Mas, para evitar abusos dos donos, já que os homens são imperfeitos, eles defendiam também que deveria existir o controle da autoridade pública quando o direito de propriedade não respeitasse sua destinação comunitária (Ceas, 1971b, pp. 45-57).

Evidentemente, uma crítica contundente feita pelo Ceas a setores marxistas e ao próprio pensamento marxiano é com relação à religião. Para Otto Maduro, no seu texto Karl 
Marx a cem anos de distância, Marx foi precipitado ao rejeitar qualquer possibilidade de contribuição da religião na libertação dos oprimidos, "Eu acho que está na hora de rejeitar esse desprezo simplista de Marx e recolocar (contra Marx) a importância e o valor do religioso numa perspectiva socialista" (Maduro, 1983, pp. 68-69). Eduard Huber foi ainda mais longe e afirmou que apesar de Marx querer a libertação do homem de todo poder coercitivo e de toda dominação de classe, ele acabou fazendo dessa libertação um fetiche ou, como o próprio autor chamou, fetichismo da libertação, pois:

"Somente a fé em Deus - o Deus que se revelou em Jesus Cristo e pagou com sua vida sua liberdade frente ao poder - é a garantia da luta contra toda a dominação do homem, contra toda exploração do homem pelo homem, contra qualquer tipo de fetichismo. Trata-se de uma fé vivida, fé naquele que é dom de si, e por isso está acima de todo poder [...] É o ideal de uma forma de existência que não pode ser dominada e que não pode querer dominar" (Huber, 1985, p. 83).

\section{À maneira de conclusão}

Em uma carta confidencial enviada pelos jesuítas do Ceas para alguns "amigos”, eles afirmaram:

"Na caminhada feita entramos em contato e colaboramos com marxistas. Nós mesmos utilizamos determinadas categorias para análise da realidade. [...] Devemos reconhecer o que foi positivo na nossa experiência: adquirimos uma visão mais concreta da realidade, conseguindo pôr em prática a orientação da Doutrina Social da Igreja. Mais que uma aquisição teórica, a utilização de instrumentos marxistas ajudou a descobrir a questão do "poder" e a procurar atitudes mais coerentes em defesa dos oprimidos e, consequentemente, atitudes mais evangélicas. 
[...] Nós pretendemos dar uma pequena colaboração na linha apontada por Dom Helder Câmara: "fazer, hoje, com Karl Marx, o que S. Tomás fez com Aristóteles”. ${ }^{6}$

Os jesuítas e leigos católicos do Ceas por motivações essencialmente religiosas dialogaram com o marxismo, como uma forma de entender as transformações pelas quais passava a sociedade brasileira no sistema capitalista e para tentar transformá-la. Eles reinterpretaram o pensamento marxista com base na sua tradição cristã contribuindo para a construção de um novo pensamento social católico.

O ponto de partida do Ceas é o pensamento Social da Igreja. O marxismo contribuiu para o entendimento da realidade brasileira e para ajudar a transformá-la, porém, o ponto de chegada é a libertação do homem, no sentido do humanismo cristão que, transcendental, "ao contrário do humanismo marxista e existencialista, assume e finaliza o desenvolvimento do homem todo e de todos os homens a divinização em Cristo". ${ }^{7}$

\section{Grimaldo Carneiro Zachariadhes}

é mestre em História Social pela UFBA e especialista em Educação pela UNEB; pesquisa o trabalho social feito pela Companhia de Jesus no Brasil no século XX.

\section{Referências bibliográficas}

\section{Caderno do CEAS}

BELDA, R. 1979. "Marxismo, cristianismo e luta de classes". Cadernos do CEAS, 64, Salvador: Centro de Estudos e Ação Social, novembro-dezembro. pp. 60-64.

${ }^{6}$ Carta dos Jesuitas do Ceas aos Amigos - Confidencial. 06/06/1980 (Arquivo do Ceas).

7 Centro de Estudos e Ação Social - Princípios e Orientações - 1968 - grifos no original (Arquivo do Ceas). 
CÂMARA, H. 1975. "Que faria S. Tomás de Aquino, o comentador de Aristóteles, diante de Karl Marx?”. Cadernos do CEAS, 37, Salvador: Centro de Estudos e Ação Social, maio/junho. pp. 52-59.

CAVAZZUTI, T. 1984. "A Propósito de um documento. Algumas distinções necessárias”. Cadernos do CEAS, 94, Salvador: Centro de Estudos e Ação Social, novembro-dezembro, pp. 74-79.

CEAS. 1971a. "Uma reflexão metodológica". Cadernos do Ceas, 12, Salvador: Centro de Estudos e Ação Social, julho, pp. 1-5.

CEAS. 1971b. "Algumas considerações doutrinárias sobre propriedade e justiça”. Cadernos do Ceas, 12, Salvador: Centro de Estudos e Ação Social, julho, pp. 45-57.

CEAS. 1972. "Dinâmica de classes na sociedade dependente". Cadernos do Ceas, 18. Salvador: Centro de Estudos e Ação Social, abril, pp. 27-48.

CEAS. 1973a. "Eu ouvi os clamores do meu povo". Cadernos do Ceas, 27. Salvador: Centro de Estudos e Ação Social, outubro, pp. 38-60.

CEAS. 1973b. "O primeiro encontro latino-americano de cristãos para o socialismo". Cadernos do Ceas, 24. Salvador: Centro de Estudos e Ação Social, abril, pp. 36-46.

CEAS. 1981. Editorial: "A Igreja na conjuntura”. Cadernos do Ceas, 73. Salvador: Centro de Estudos e Ação Social, maio-junho, pp. 3-6.

140 CEAS. 1982. "A teoria e as exigências da prática”. Cadernos do Ceas, 77. Salvador: Centro de Estudos e Ação Social, janeiro-fevereiro, pp. 57-58.

CEAS. 1993. "O Ceas em 10 minutos". Cadernos do Ceas, 193. Salvador:

Centro de Estudos e Ação Social, janeiro-fevereiro, pp. 61-62.

FOUREZ, G. 1975. "Luta de classes e comunhão cristã". Cadernos do Ceas, 36. Salvador: Centro de Estudos e Ação Social, março-abril, pp. 41-46. GIRARDI, J. 1972. "A luta de classes e os excluídos”. Cadernos do Ceas, 22. Salvador: Centro de Estudos e Ação Social, dezembro, pp. 51-58.

HUBER, E. 1985. "A libertação do homem segundo Marx". Cadernos do Ceas, 100. Salvador: Centro de Estudos e Ação Social, novembro-dezembro, pp. 74-83.

MADURO, O. 1983. "Karl Marx a cem anos de distância”. Cadernos do Ceas, 86. Salvador: Centro de Estudos e Ação Social, julho-agosto, pp. 66-70.

NELL-BREUNING, O. Von. 1970. "Igreja Católica e crítica marxiana do capitalismo". Cadernos do Ceas, 7. Salvador: Centro de Estudos e Ação Social, junho, pp. 1-11.

PERANI, C. 1977. "Pobres e ricos". Cadernos do Ceas, 48. Salvador: Centro de Estudos e Ação Social, março-abril, pp. 52-60.

PERANI, C. 1980. "Libertação e espiritualidade". Cadernos do Ceas, 66. Salvador: Centro de Estudos e Ação Social, março-abril, pp. 62-72. 


\section{Outras Publicações}

ARRUPE, P. 1976. "Fome de pão e evangelização". Coleção Ignatiana, nº 5 , pp. 5-24.

ARRUPE, P. 1981. "Análise marxista”. Coleção Ignatiana, n 17, pp. 5-13.

AZEVEDO, F. A. 1986. Missão Portuguesa da Companhia de Jesus no Nordeste (1911-1936). Pernambuco: FASA - Fundação Antônio dos Santos Abranches.

BEOZZO, J. O. 1993. A Igreja do Brasil: de JOÃO XXIII a João Paulo II, de Medellín a Santo Domingo. Petrópolis, RJ: Vozes.

BOFF, L. (org). 1996. A Teologia da Libertação - Balanços e perspectivas. São Paulo: Ática.

CALVEZ, J.-Y. 1959. O pensamento de Karl Marx. (2 Vol.). Porto: Livraria Tavares Martins.

CNBB. 1963. Plano de emergência para a Igreja do Brasil. São Paulo: Paulinas.

ENGELS, F. 1972. "Contribuição para a história do cristianismo primitivo”. In: MARX, K.; ENGELS, F. Sobre a Religião. Lisboa: Edições 70.

FLORIDI, U. A. 1973. O radicalismo católico brasileiro. São Paulo: Hora Presente.

GARAUDY, R. 1966. Do anátema ao diálogo. Rio de Janeiro: Editora Paz e Terra.

“Gaudium et Spes”. 1966. Constituição Pastoral do Concílio do Vaticano II sobre a Igreja no mundo de hoje. São Paulo: Paulinas.

GOZZINI, M. (org). 1968. Diálogo posto à prova. Debate entre católicos e comunistas italianos. Rio de Janeiro: Paz e Terra.

GUTIÉRREZ, G. 1979. Teologia da Libertação-Perspectivas. 3. ed. Petrópolis, RJ: Vozes.

KONDER, L. 1978. "Marxismo e Cristianismo". Revista Encontros com a civilização brasileira, 6 - Número Especial: Rio de Janeiro: Civilização Brasileira, pp. 57-65.

LEÃO XIII. 1891. Rerum Novarum. São Paulo: Paulinas, 15 de maio.

LEHMANN, P. 1966. "Ética cristã, ética marxista" Revista Paz e Terra, 1: Rio de Janeiro: Paz e terra, julho, pp. 154-162.

LÖWY, M. 2000. A guerra dos deuses. Religião e política na América Latina. Petrópolis, RJ: Vozes.

"Manifesto do episcopado brasileiro sobre a ação social". 1946. Revista Eclesiástica Brasileira vol. 6, Fascículo 2, Petrópolis, RJ: Vozes, junho, pp. 479-484.

MARANHÃO, L. 1968. "Marxistas e católicos: da mão estendida ao único caminho". Revista Paz e Terra, 6: Rio de Janeiro. Ed. Paz e Terra, abril, pp. 57-71. 
MARX, K. 1972. "Crítica da filosofia do Direito de Hegel”. In: MARX, K.; ENGELS, F. Sobre a Religião. Lisboa: Edições 70.

MARX, K.; ENGELS, F. 1984. A ideologia alemã. Teses sobre Feuerbach. São Paulo: Moraes.

ORFEI, R. 1968. "Não inimigos e sim irmãos separados". In: GOZZINI, M. (org). Diálogo posto à prova. Debate entre católicos e comunistas italianos. Rio de Janeiro: Paz e Terra, pp. 167-191.

PALÁCIO, C. (org.). 1982. Cristianismo e história. São Paulo: Loyola.

"Pastoral Coletiva do Episcopado Paulista sobre alguns erros contra a fé e a moral”. 1941. Revista Eclesiástica Brasileira vol.1. Fascículo 4. Petrópolis, RJ: Editora Vozes, dezembro, pp. 889-901.

PAULO VI. 1967. Populorum progressio. São Paulo: Paulinas, 26 de março. PIO XI. 1931. Quadragesimo anno. São Paulo: Paulinas, 15 de maio. PIO XI. 1937. Divini Redemptoris. São Paulo: Paulinas, 19 de março. PIO XI. 3/5/1932. "Caritate Christi Compulsi”.1967. Magistério Social da Igreja: de Pio IX a Pio XII: 1864 - 1958. São Paulo: Paulinas.

PRANDINI, F.; PETRUCCI, V. A.; DALE, R. (orgs.). 1986. As relações IgrejaEstado no Brasil (1964-1967). Durante o governo do Marechal Castelo Branco - volume I. Centro Pastoral Vergueiro. São Paulo: Loyola.

RADICE, L. L. 1968. "Um marxista diante de fatos novos no pensamento e na consciência religiosa”. In: GOZZINI, M. (org.). Diálogo posto à prova. Debate entre católicos e comunistas italianos. Rio de Janeiro: Paz e Terra, pp. 73-94.

REGIDOR, J. R. 1996. "Vinte e cinco anos de teologia da Libertação". In: BOFF, Leonardo (org.). A Teologia da Libertação - Balanços e perspectivas. São Paulo: Ática.

SOUZA, G. E. S. 1994. Entre o religioso e o político: uma história do círculo Operário da Bahia. Dissertação de Mestrado em História. Salvador: Ed. UFBA.

VERRET, M. 1966. "Um marxista diante da Igreja Católica”. Revista Paz e Terra, 1: Rio de Janeiro: Paz e Terra, Julho de pp.163-179.

ZACHARIADHES, G. C. 2009. Ceas: jesuitas e o apostolado social durante a ditadura militar. Salvador: Ed. UFBA. 


\section{QUE FEZ SÃO TOMÁS DE AQUINO DIANT}

GRIMALDO CARNEIRO ZACHARIADHES

O artigo aborda o diálogo de setores da Igreja Católica com o pensamento marxista. É privilegiado neste trabalho o Centro de Estudos e Ação Social (Ceas), uma instituição fundada pelos jesuítas na Bahia. Procurarei demonstrar como esta instituição da Companhia de Jesus reinterpretou o marxismo com base na sua visão cristã, contribuindo para a construção de um novo pensamento social católico no Brasil, durante a segunda metade do século XX.

E DE KARL MARX

Palavras-chave: Companhia de Jesus; Marxismo; Ceas; Igreja Católica.

\section{WH}

